\title{
RP-HPLC Method Development and Validation for Determination of Didanosine in Pharmaceutical Dosage Forms
}

\author{
Sachin Gholve ${ }^{*}$, Sharddha Gangapure ${ }^{1}$, Mahesh Birajdar², Imran Mujewar1, Omprakash G Bhusnure ${ }^{1}$ \\ ${ }^{1}$ Department of Quality Assurance, Channabasweshwar Pharmacy College (Degree), Kava Road, Basweshwar Chowk, Latur, Maharashtra, India-
} 413512

2Department of Pharmaceutical Chemistry, Channabasweshwar Pharmacy College (Degree) Kava Road, Basweshwar Chowk, Latur, Maharashtra, India-413512

\begin{abstract}
To develop a simple, cheap, accurate, and rapid Reverse Phase High Performance Liquid Chromatographic (RP-HPLC) method and validate as per ICH guidelines for estimation of Didanosine in pharmaceutical dosage forms. The separation was conducted by using mobile phase consisting of methanol: water in the ratio (30:70). The wavelength was found at 246nm. Agilent 1220 Infinity LC with ezchrome software is

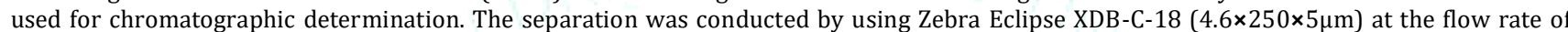
$1.0 \mathrm{ml} / \mathrm{min}$ using variable wavelength detector. The developed method resulted in didanosine eluting at 4.650 min. The method was found to be linear over the concentration range $2-12 \mu \mathrm{g} / \mathrm{ml}$ with coefficient regression R2-0.997. Mean recovery was found to be in the range of $99.99 \%$ during accuracy studies. The limit of detection (LOD) and limit of quantitiation (LOQ) was found to be $5 \mathrm{mg} / \mathrm{ml}$ and $16 \mathrm{mg} / \mathrm{ml}$ respectively. A cheap, accurate, precise, linear and rapid RP-HPLC method was developed and validated for the quantitative estimation of Didanosine as per ICH guidelines.
\end{abstract}

Keywords:-RP-HPLC, Didanosine, Method Validation

Article Info: Received 18 June 2019; $\quad$ Review Completed 24 July 2019; $\quad$ Accepted 28 July 2019; Available online 15 August 2019

Cite this article as:

Gholve S, Gangapure S, Birajdar M, Mujewar I, Bhusnure OG, RP-HPLC Method Development and Validation for Determination of Didanosine in Pharmaceutical Dosage Forms, Journal of Drug Delivery and Therapeutics. 2019; 9(4s):343-347 http://dx.doi.org/10.22270/jddt.v9i4-s.3328

*Address for Correspondence:

Sachin Gholve, Department of Quality Assurance, Channabasweshwar Pharmacy College (Degree), Kava Road, Basweshwar Chowk, Latur, Maharashtra, India-413512

\section{INTRODUCTION:}

Didanosine chemically 2', 3'- dideoxyinosine (fig1) is an antiretroviral medication used to treat HIV/AIDS in combination with other medications as part of highly active antiretroviral therapy. An extensive review of the literature revealed a few analytical methods (1-12), was reported for the estimation of didanosine in dosage forms. Didanosine is a dideoxy analogue of the purine nucleoside inosine that potentially inhibits the replication of the human immunodeficiency virus. Analogue to other nucleoside inhibits, this compound also requires intracellular metabolism to the active triphosphate, 2', 3'- dideoxyinosine5-triphosphate (ddATP), which act as a competitive inhibitors of HIV reverse transcriptase or as a DNA chain transmitter. (13-14) Validation is the process of providing documented evidence what it is intended to do. In other word the process of method validation ensures that the proposed analytical methodology is accurate, specific, reproducible and rugged for its intended use. Analytical techniques have different degrees of sophistication, sensitivity and selectivity, as well as, different cost and time requirements.

\section{MATERIALS AND METHODS}

\section{Chemicals and Reagents}

Water, Methanol, Acetonitrile of Analytical and HPLC grade purchased from Arti pharmaceuticals (Mumbai). Ammonium acetate buffer of AR grade purchased from Raj Chemicals (Latur).

\section{Instrument}

HPLC analysis was performed on Agilent 1220 Infinity LC with EZchrome software with variable wavelength detector. With made of Agilent technologies, A manually operating Rheodyne injector with $20 \mu$ l sample loop was equipped with the HPLC system.,Zobrax Eclipse XDBC18 column $(4.6 \times 150 \times 5 \mu \mathrm{m})$, Electronic weighing balance BL-220 H 
made of Shimatzu Corporation, Hot air oven made of Nisco Company, Sonicator made of the Ultrasonic's PCi Analytics sonicator.

METHODS:- Selection of Wavelength suitable wavelength for the HPLC analysis was determined by recording UV spectrum in the range of $200-400 \mathrm{~nm}$ for didanosine. Suitable wavelength selected was $246 \mathrm{~nm}$ (Figure 2).

Figure 1 Chemical structure of Didanosine<smiles>O=c1[nH]cnc2c1ncn2[C@H]1CC[C@@H](CO)O1</smiles>

Figure 2 UV spectrum of Didanosine

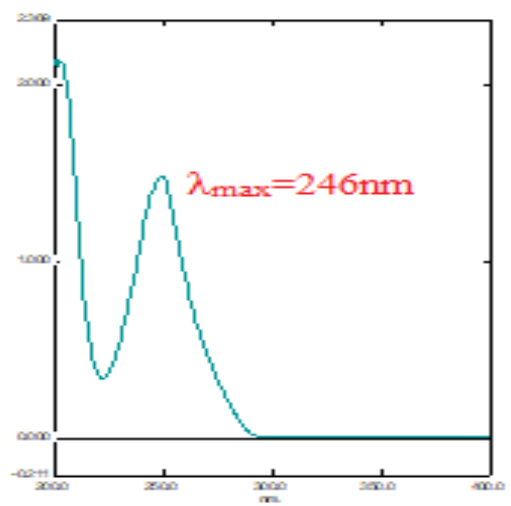

Figure 3 Typical Chromatogram of Blank solution

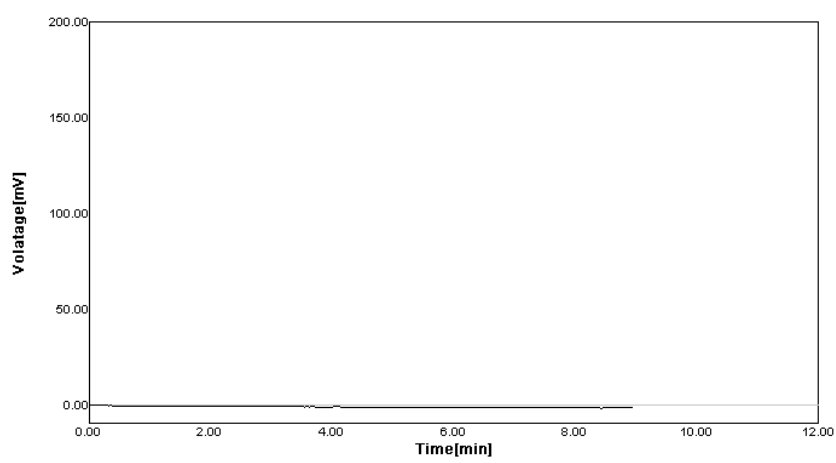

Figure 4 Typical chromatogram of the standard solution

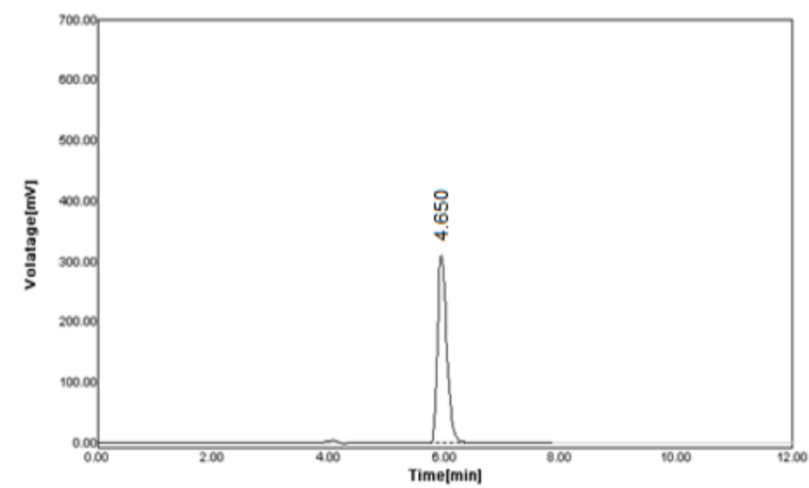

Figure5 Typical chromatogram for the tablet formulation

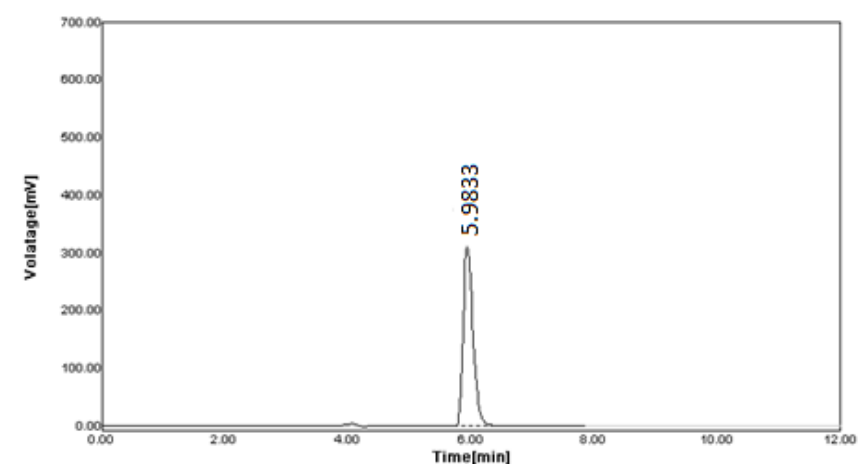

Figure 6 Calibration Curve

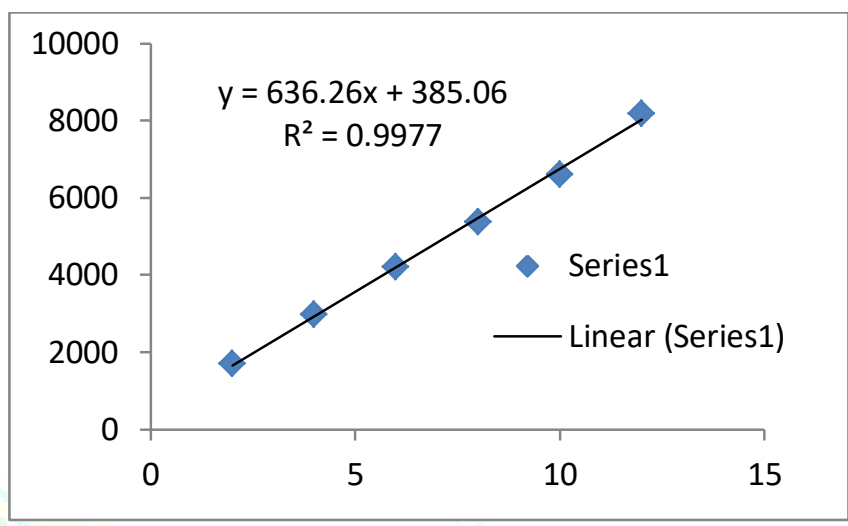

\section{CHROMATOGRAPHIC CONDITIONS:}

The developed method uses a reverse phase C18 column, Phenomena Gemini (C18 $4.6 \times 250 \times 5 \mu \mathrm{m})$, mobile phase consisting of a mixture of methanol: water in the ratio (30:70). The mobile phase was set at a flow rate of $1 \mathrm{ml} / \mathrm{min}$ and the volume injected was $20 \mu \mathrm{l}$ for every injection. The detection wavelength was set at $246 \mathrm{~nm}$.

\section{Preparation Mobile Phase}

A mixture of 30 volumes of Methanol, and 70 volumes of water was prepared (30:70). The mobile phase was sonicate for $10 \mathrm{~min}$ to remove gases.

\section{Preparation of standard stock solution}

Weigh accurately $10 \mathrm{mg}$ of Didanosine drug in $100 \mathrm{ml}$ volumetric flask and dissolve in $100 \mathrm{ml}$ water.

\section{Preparation of sample solution}

20 Tablets (each tablet contains $10 \mathrm{mg}$ of Didanosine) were weighed and taken into a mortar uniformly mixed. Test stock solutions of Didanosine $(10 \mu \mathrm{g} / \mathrm{ml})$ and was prepared by dissolving weight equivalent to $10 \mathrm{mg}$ of Didanosine and dissolved in sufficient mobile phase. After that filtered the solution using 0.45 -micron syringe filter .after the filtration zsolicited for $5 \mathrm{~min}$ and dilute to $100 \mathrm{ml}$ with mobile phase. Further dilutions are prepared in 5 replicates of $10 \mu \mathrm{g} / \mathrm{ml}$ of Didanosine was made by adding $1 \mathrm{ml}$ of stock solution to 10 $\mathrm{ml}$ of mobile phase.

\section{Calibration Curve}

Appropriate aliquots of standard stock solution $(1000 \mu \mathrm{g} / \mathrm{ml})$ was diluted to $100 \mathrm{mg} / \mathrm{ml}$ in $10 \mathrm{ml}$ volumetric flask and resultant solution was diluted up to the mark with mobile phase to obtain a final concentration of 2,4,6,8,10, and $12 \mu \mathrm{g} / \mathrm{ml}$. These solutions were injected into 
chromatographic system. The chromatograms were obtained and peak area ratio was determined for each concentration of drug solution. Calibration curve of Didanosine were constructed by plotting peak area ratio vs applied concentration of Didanosine and regression equation was computed. The sample solution was chromatographic and concentration of didanosine in tablet samples was calculated using regression equation.

\section{RESULTS AND DISCUSSION}

\section{METHOD DEVELOPMENT}

A Reverse phase HPLC method was developed considering the system suitability parameters i.e. tailing factor (T), the number of theoretical plates $(\mathrm{N})$, run time and the cost effectiveness. The optimized method developed resulted in the elution of Didanosine at $4.560 \mathrm{~min}$. Figures $3 \& 4$ represent chromatograms of blank and standard solution $(10 \mu \mathrm{g} / \mathrm{ml})$ respectively. The total run time is 10 minutes. System suitability tests are an integral part of method development and validation. System suitability tests are used to ensure adequate performance of the chromatographic system. System suitability parameters were evaluated for six replicate injections of the standard at working concentration. The results are given in Table 1.
Table 1 System suitability studies results

\begin{tabular}{|c|c|}
\hline Parameters & Didanosine \\
\hline Retention time (min) & 4.650 \\
\hline $\begin{array}{c}\text { Number Of Theoretical } \\
\text { plates(N) }\end{array}$ & 6245 \\
\hline Tailing factor (T) & 1.6 \\
\hline
\end{tabular}

Table 2 Calibration data for Didanosine

\begin{tabular}{|c|c|c|}
\hline Sr. No & Concentration $(\mu \mathrm{g} / \mathrm{ml})$ & Area $(\mu \mathrm{AU})$ \\
\hline 1 & 2 & 169062 \\
\hline 2 & 4 & 298014 \\
\hline 3 & 6 & 419805 \\
\hline 4 & 8 & 537160 \\
\hline 5 & 10 & 660275 \\
\hline 6 & 12 & 818992 \\
\hline
\end{tabular}

Table 3 Results of Accuracy studies for Didanosine

\begin{tabular}{|c|c|c|c|c|c|c|}
\hline Recovery level & & & Accuracy & anosine & & \\
\hline & $\begin{array}{l}\text { Amount of } \\
\text { taken }\end{array}$ & Area & Average Area & $\begin{array}{c}\text { Amount } \\
\text { recovered } \\
(\mathrm{mcg} / \mathrm{ml})\end{array}$ & \% Recovery & $\begin{array}{c}\text { Average \% } \\
\text { Recovery }\end{array}$ \\
\hline \multirow{3}{*}{80} & 2 & 169062 & \multirow{3}{*}{168764} & \multirow{3}{*}{1.94} & \multirow{3}{*}{$96 \%$} & \multirow{9}{*}{$97 \%$} \\
\hline & 2 & 169072 & & & & \\
\hline & 2 & 168159 & & & & \\
\hline \multirow{3}{*}{100} & 6 & 419805 & \multirow{3}{*}{419310} & \multirow{3}{*}{5.94} & \multirow{3}{*}{$98 \%$} & \\
\hline & 6 & 419710 & & & & \\
\hline & 6 & 418415 & & & & \\
\hline \multirow{3}{*}{120} & 10 & 660275 & \multirow{3}{*}{660750} & \multirow{3}{*}{9.8} & \multirow{3}{*}{$97 \%$} & \\
\hline & 10 & 661165 & & & & \\
\hline & 10 & 660945 & & & & \\
\hline
\end{tabular}

Table 4 System precision results

\begin{tabular}{|c|c|c|}
\hline Didanosine & & \\
\hline Injection No. & $\mathrm{Rt}$ & Area \\
\hline 1 & 4.631 & 670254 \\
\hline 2 & 4.650 & 675148 \\
\hline 3 & 4.550 & 670254 \\
\hline 4 & 4.642 & 674545 \\
\hline 5 & 4.551 & 676458 \\
\hline 6 & 4.650 & 673654 \\
\hline $\mathrm{AVG}$ & 4.612333 & 673385.5 \\
\hline SD & 0.0484011 & 2591.362 \\
\hline$\% \mathrm{RSD}$ & 1.04938 & 0.4848 \\
\hline
\end{tabular}

Table 5 Intraday precision results

\begin{tabular}{|c|c|c|}
\hline Injection No. & Rt & Area \\
\hline 1 & 5 & 664257 \\
\hline 2 & 5.01 & 664747 \\
\hline 3 & 4.99 & 664346 \\
\hline 4 & 4.99 & 664421 \\
\hline 5 & 5.1 & 664237 \\
\hline 6 & 5 & 664647 \\
\hline AVG & 5.015 & 664452 \\
\hline SD & 0.0423 & 210.216 \\
\hline \%RD & 0.8623 & 0.31 \\
\hline
\end{tabular}


Table 6 Inter day precision results

\begin{tabular}{|c|c|c|}
\hline Injection No. & Rt & Area \\
\hline 1 & 4.655 & 664803 \\
\hline 2 & 4.7 & 66472 \\
\hline 3 & 4.95 & 66509 \\
\hline 4 & 4.60 & 66429 \\
\hline 5 & 4.90 & 66501 \\
\hline 6 & 4.70 & 66519 \\
\hline AVG & 4.7508 & 664850.5 \\
\hline SD & 0.14072 & 326.039 \\
\hline \%RSD & 1.20 & 0.490 \\
\hline
\end{tabular}

Table 7 Robustness results of Didanosine

\begin{tabular}{|c|c|c|}
\hline \multicolumn{3}{|c|}{ Parameters } \\
\hline \multicolumn{3}{|c|}{ Flow } \\
\hline $0.8 \mathrm{mn} / \mathrm{min}$ & 4.7283 & 672957 \\
\hline $1.2 \mathrm{ml} / \mathrm{min}$ & 4.885 & 67296 \\
\hline \multicolumn{3}{|c|}{ Wavelength } \\
\hline 244 & 4.7866 & 67338.5 \\
\hline 248 & 4.6866 & 674228.3 \\
\hline
\end{tabular}

\section{METHOD VALIDATION (15-16)}

Authentification of the investigative method is the process that starts by laboratory studies in which the requirements of the performance properties of method are met for the intended analytical application. To the validation of analytical procedures RP-HPLC method developed was validated according to International Conference on Harmonization (ICH) and USP guidelines. Various parameters or criteria are used for the method of validification, such as linearity, accuracy, precision, system suitability, ruggedness, limit of Quantification (LOQ) and limit of Detection (LOD).

\section{System suitability parameters}

The system suitability parameters were determined by preparing standard solutions of Didanosine. The solutions were injected six times and the parameters are calculated which are \% RSD, peak tailing, resolution and USP plate count. The results are mentioned in Table 1 . The standard chromatogram is shown in Fig. 4.

\section{Specificity}

Figures 3-5 are for the blank determination, the standard drug solution and sample chromatograph mixture discloses that the peaks acquired in the standard solution and sample solution at working concentrations are acquired only because of the drugs, this is the reason that blank determinations show no peak at the retention time of didanosine. Accordingly it can be concluded that, the method developed is said to be accurate and specific.

\section{Linearity}

Linearity the method was tested from $80-120 \%$ of the targeted level of the assay concentration for analyte. Standard solutions contained $2-12 \mu \mathrm{g} / \mathrm{mL}$ of didanosine.
Linearity solutions were injected in triplicate. The equations of the calibration curves for Montelukast sodium obtained were $\mathrm{y}=02 \mathrm{E}+06 \mathrm{X}$ in the didanosine determination, the calibration graphs were found to be linear in the aforementioned concentrations with correlation coefficients 0.9978. The results are mentioned in the Table 2 \& calibration curve Fig 6.

\section{Accuracy}

The precision was determined with the help of recovery experiments, by the verification with percentage mean recovery of sample at three different levels (80-120\%). 20 blank tablets were powdered and mixed. This powder was then spiked with a quantity of didanosine corresponding to $80 \%, 100 \%$ and $120 \%$ of the labeled claim. Each of these powder mixtures was analyzed in triplicate and the quantity of Didanosine was determined using calibration equation. Accuracy was reported as $98 \%$ of didanosine recovered. The results are mentioned in Table 3.

\section{Precision}

\section{System precision}

The value for \%RSD (Relative Standard Deviation) was obtained less than 2 by six replicate injections of the standard solution at working concentrations, concerning the peak area for the drug. It designates the adequate reproducibility and hence the accuracy of the system. System precision results are tabulated in Table 4.

\section{Method precision}

The accuracy of procedure was determined by conducting assay of sample with the tests of (I) Repeatability (Intraday precision) and (II) Intermediate precision or ruggedness (Interday precision) completed within 3 successive daysbythree different analysts, at working concentration.

\section{Repeatability (Intraday precision)}

The value for \%RSD (Relative Standard Deviation) less than 2 for six successive injections of the sample solution from the same homogenous mixture at working concentrations, concerning $\%$ assay for the drug which indicate that the method developed is method precise by the test of repeatability and hence can be understood that the method gives consistently reproducible results (Table 5).

\section{Intermediate Precision (Ruggedness / Inter day precision)}

The value for \%RSD (Relative Standard Deviation) less than 2 for six successive injections of the sample solution from the same homogenous mixture at working concentrations on three successive days by three unidentical analysts for \% assay for the drug within and between days, which indicate the method developed is inter day precise / rugged (Table 6).

\section{Robustness}

The robustness of an analytical procedure is an estimate of its capacity to last unchanged by slight but intentional change in the analytical method parameters. To assess HPLC method robustness some measurable factors were intentionally changed. The factors comprise of variation of columns C8 (old \& new), \% of acetonitrile in the moving stage and acetonitrile of lots. Change in wavelength $\pm 2 \mathrm{~nm}$ Change in flow rate $\pm 0.2 \mathrm{ml} / \mathrm{min}$. The results are mentioned in Table 7. 


\section{Limit of Detection (LOD)}

The limit of detection (LOD) of methodological (analytical) process is defined as the concentration that produce instrument signal that is notably distinct from the blank determination. The IUPAC approach utilize the standard deviation of the intercept (Sa) for the spectroscopic techniques or other methods that depend upon a calibration curve for quantitative measurements, which may be related to LOD and the slope of the calibration curve, b. The limit of detection was found to be $5 \mathrm{ng} / \mathrm{ml}$

\section{Limit of Quantification (LOQ)}

The LOQ is the concentration that can be quantitate reliably with a specified level of accuracy and precision. The LOQ represent the concentration of analyte that would yield a signal-to-noise ratio of 10 .The limit of quantification was found to be $15 \mathrm{mg} / \mathrm{ml}$.

\section{CONCLUSION}

Method development and validation of model drug Didanosine was carried out under the circumstances of using mobile Water which give sharp peak and UV spectra also. A very few analytical method found in literature survey for the determination of Didanosine including FTIR, spectrophotometer. The develop UV and HPLC method was found to be simple, rapid, selective accurate, precise for the concurrent estimation of drug in dosage form. The method was evaluated in best condition, linear relation including coefficient of correlation, linearity, robustness, and accuracy, precision. The percent RSD for all parameter was found to be less than two which indicate the validity of method and assay result obtained by this method are in fair agreement. The force degradation studies performing in acidic, basic, neutral, Photo stability also performed.

All result obtained with proposed method confirm the suitability of these method for the analysis of pharmaceutical dosage form. The proposed method has been successfully applied for routine in process quality control.

\section{ACKNOWLEDGMENT:}

The authors take this opportunity thanks to Aarati Pharmaceuticals, Mumbai for providing gift sample. The authors would like to acknowledge Principal Dr. Vijayendra Swamy S. M., Principal, Channabasweshwar Pharmacy College, Latur for providing facilities for conducting research.

\section{REFERENCES:}

1. Shanta Kumar, K. Prakash, K.E.V. Nagoji And M.E.B. Rao, Determination of Didanosine in pharmaceutical dosage forms by RP-HPLC, Asian Journal of Chemistry, 2007; 19(4): 26332636.
2. J. N. Sangshetti, P. A. Kulkarni, and D. B. Shinde, Spectrophotometric determination Didanosine in bulk and tablet formulation, trend in applied science research, 2007; 2(1): 71-75.

3. N. Jaiprakash, Sangshetti, A. Parag Kulkarni and B. Devanand Shinde. Spectrophotometric Determination of Didanosine in Bulk and Tablet Formulation. Trends in Applied Sciences Research, 2007; 2: 71-75.

4. K. L. Senthil Kumar, S. Ashokkumar, R. P. Ezhilmuthu, Formulation and Evaluation of Didanosine Enteric Coated Sustained Release Tablet J Biomed Sci and Res., 2010; 2(3): 126-131.

5. R. N. Kane, P. S. Bhokare, C. C. Nalawade, M. S. Sayyed and R. D. Paliwal, Spectrophotometric Estimation of Didanosine in Bulk Drug and its Formulation, International Journal of Pharmaceutical And Chemical Sciences, 2012; 1(4): 22775005 .

6. A. Manikanta kumar, B. N. Sandhya, M. Nasare, VVLN Prasad and P. V. Diwan, Development and Validation of UV Spectrophotometric Method for Simultaneous Estimation of Lamivudine, Didanosine and Efavirenz in the Pharmaceutical Dosage form, American Journal of PharmTech Research, 2012; 2(6): 2249-3387.

7. F. Alatas, S. N. Soewandhi, L. Sasongko and Ismunandar, Simultaneous determination of Didanosine And Nicotinamide in binary mixture by first derivative UV spectrophotometry, International Journal of Pharmaceutical Sciences Review and Research, 2012; 17(1): 7-10.

8. Patricia Severinoa b, H. Silvac, E. B. Souto, Maria Helena A. Santanaa and Teresa Cristina T. Dalla Costab, Analysis of in vivo absorption of didanosine tablets in male adult dogs by HPLC, Journal of Pharmaceutical Analysis, 2012; 2(1): 29-34.

9. R. Revathi , S.P. Naga, R.M. Koteswara, T. Ethiraj and S. Rajarajan, Development and validation of RP-HPLC method for content analysis of Didanosine in dosage form, Asian Journal of Pharmaceutical Analysis, 2012; 2(4): 118-121.

10. S. B. Naga, A. Manikanta, M. K. Nasare, Vijay Kumar P., S. Jetta And P. V. Diwan, RPHPLC method for simultaneous estimation of Lamivudine, Didanosine And Efavirenz in pharmaceutical dosage forms, Der Pharmacia Lettre, 2013; 2(3): 148-155.

11. Gauri Santosh Kulkarni, Chandrashekhar Ashok Kale, Vitthal V.Chopade, and Pravin. D. Chaudhari, development and validation of a stability indicating uv-vis spectrophotometric assay method of didanosine by using different stress degradation conditions, world journal of pharmacy and pharmaceutical sciences, 2014; 3(8): 600-611.

12. G. Ramesh, M. Subba Rao, development and validation of new Uv-spectrophotometric assay mehod ofr didanosine in pure and in formulations, Bulletin of Pharmaceutical and Medical Sciences, 2015; 3(1): 3034-3039

13. E.J De Clercq, Clin. Virol.30(2004) 115-133

14. E.De Clercq,int. J.Biochem.cell Biol.36 (2004)1800-1822.

15. International Conference on Harmonization of Technical Requirements for Registration of Pharmaceuticals for Human use. Validation of Analytical Procedures: Text and Methodology ICH Q2 (R1). 2005.

16. Ewing GW. Instrumental methods of chemical analysis, 5th ed., McGraw Hill International Publication. Chemistry Series; 1985. P.1-4. 